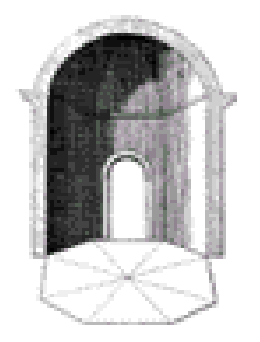

\title{
Grenzen en mogelijkheden van een personalistische bedrijfsethiek
}

\author{
Mark Coeckelbergh - University of Birmingham
}

In zijn essay 'Mounier en de utopie van een economische democratie' (Bouckaert 2000) geeft Luk Bouckaert een uitstekende beschrijving van het personalisme van Mounier. Helaas blijft het daarbij. Op enkele suggesties en eindbedenkingen na is er weinig kritische analyse en eigen argumentatie in te vinden. Jammer, want daardoor blijven zowel mogelijkheden als problemen van deze opvatting m.b.t. het denken over bedrijfsethiek en economische democratie onderbelicht. In dit essay zou ik daartoe een kleine bijdrage willen leveren. In het bijzonder wil ik aantonen dat het personalisme zijn inspirerende kracht voor de hedendaagse maatschappelijke problemen in het algemeen en bedrijfsethische vraagstukken in het bijzonder enkel kan behouden (of krijgen) als hedendaagse én traditionele gedachten die de verbondenheid van mens en natuur beklemtonen, erin worden verwerkt.

\section{Probleemstelling}

In tegenstelling tot wat Bouckaert lijkt te beweren (2000: 221) is de economische wetenschap geen theoretisch kader dat los van ideologische beschouwingen kan gezien worden. Het is niet omdat ideologische verhalen door beleidsmensen en bedrijven nauwelijks nog verteld worden, dat er geen verhaal is. De economische wetenschap, het huidige beleid, en de manier waarop economie en bedrijven hier zijn georganiseerd en gestructureerd zijn sterk verbonden met (vooral) de kapitalistische ideologie en (in mindere mate) de socialistische/communistische ideologie. Alhoewel beide ideologieën op veel punten enorm verschillen, zijn er fundamentele overeenkomsten betreffende hun mens- en wereldbeeld, o.a. antropocentrisme (de mens staat in het centrum) en een instrumentele houding ten opzichte van de natuur: de natuur staat mij (ik, de staat, de economie) ter beschikking als iets waarover ik heers. Het personalisme (van Mounier) verschilt op deze punten niet wezenlijk van kapitalisme en communisme. De (menselijke) persoon wordt in het centrum geplaatst, en alhoewel men elk systeemdenken afwijst (de economie als systeem in het kapitalisme en de staat als systeem in het communisme) en instrumentalisering van de mens als persoon wil tegengaan, blijft de natuur instrument van de mens, ook als deze mens als persoon wordt gezien. Verder blijft men ook wat het denken over economie en bedrijfsethiek betreft vooral op producenten, werknemers, en (meer recent) consumenten gericht zonder andere relaties en belangen een essentiële rol toe te kennen in het economische beslissings- en organisatiekader (op bedrijfsniveau, nationaal niveau, internationaal niveau). Deze kritiek is niet nieuw, zij is de laatste decennia veel geuit en langzaam uitgegroeid tot een eigen 'verhaal', maar het is wel een kritiek waarop het personalisme een antwoord moet vinden. Omdat een dergelijke uiteenzetting ontbreekt in Bouckaerts essay, zie ik mij genoodzaakt enkele ideeën en problemen hieromtrent te schetsen.

\section{Problemen, grenzen}

Mouniers personalisme stelt voor de economie te democratiseren. Dit zou betekenen dat de werknemer volwaardig participeert en meebeslist in het bedrijf, en op die manier geëmancipeerd wordt. De economische democratie houdt dan niet alleen een eventuele financiële participatie in (deelname in de winst), maar ook beleidsparticipatie (Bouckaert 2000: 228). Bouckaert beklemtoont het belang van het menselijk en sociaal kapitaal en breekt (helemaal op het einde van het artikel) nog even een lans voor de stakeholdervennootschap (2000: 
f 


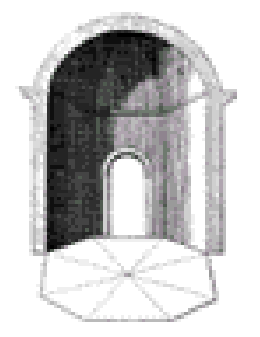

Hoe interessant en (wellicht) noodzakelijk deze ideeën ook zijn, het wordt duidelijk dat in hun huidige vorm zowel Mouniers basisidee als Bouckaerts voorzichtige amendementen niet toereikend zijn om een bedrijfsethiek te ontwikkelen die een antwoord kan bieden op de hedendaagse maatschappelijke uitdagingen. De mogelijkheid dat ook een democratische economie in deze vorm wellicht niet voldoende is, wordt onbesproken gelaten. En alhoewel Bouckaert het heeft over 'duurzaam vertrouwen' en 'inbreng van ecologisch of sociaal kapitaal', wordt een mogelijke discussie tussen het (traditionele) personalisme en nieuwe ideeën omtrent economische democratie niet eens echt gestart, laat staan uitgewerkt.

In de traditie van het liberalisme maar ook voor een stuk van het personalisme wordt een bedrijf (en uiteindelijk de ganse economie) vooral gezien als een aparte entiteit die te maken heeft met aandeelhouders, management, werknemers, en (in mindere mate) klanten of consumenten. De relaties tussen het bedrijf en vele delen van de bredere samenleving en vooral deze tussen het bedrijf en de natuur worden dikwijls buiten het blikveld gehouden. In het bijzonder worden de volgende mensen of belangen ver buiten elke beslissingsstructuur of economische machtcentra gehouden:

- de belangen van de niet-consumenten of niet-

klanten: zij brengen geen geld op voor het bedrijf maar dragen wel heel wat kosten; nochtans kunnen zij niet opkomen voor hun belangen binnen het bedrijf

- de belangen van de ongeborenen: toekomstige generaties dragen de last van huidige economische beslissingen, maar kunnen zich niet verdedigen

- de natuur, toch nog steeds ons leefmilieu: kan zich niet verdedigen in het bedrijf

Deze kritiek is niet wereldschokkend nieuw, maar is wel iets waar het personalisme moet op antwoorden. Het traditionele model van Mounier heeft het over een ethiek van de consumptie en een ethiek van de productie (Bouckaert 2000: 227), waardoor een hele wereld buiten het gebied van zijn ethiek valt. De economie wordt nog teveel gezien als een aparte sfeer. Het bedrijf is een burcht die eigenlijk geen inmenging van 'buitenstaanders' duldt in de beslissingen die 'binnen' genomen worden. Deze grens tussen binnen en buiten is echter een illusie die door recht, politiek en cultuur in stand wordt gehouden. Het is een illusie omdat er veel meer verbanden zijn tussen wat een bedrijf beslist en doet aan de ene kant, en wat gebeurt in de samenleving en het leefmilieu aan de andere kant.

We zien dat hier twee modellen tegen mekaar aanbotsen. Het ene benadrukt de autonomie van het bedrijf (waarin desnoods de werknemers medezeggenschap hebben), het andere beklemtoont de intrinsieke verbondenheid van het bedrijf met allen en alles. Het personalisme zoals dit geschetst wordt in Bouckaerts artikel lijkt vooral het eerste model te hanteren. Is er een alternatief? En is dit een alternatief dat ook door het personalisme geïnspireerd kan worden?

\section{Mogelijkheden}

Het personalisme staat als deel van het christelijke mensbeeld in een positie van concurrentie met holistisch en ecologisch denken. In feite wordt het daardoor in een defensieve positie gedwongen. Ten eerste is er het verwijt van antropocentrisme. Dit verwijt is terecht. De vraag is echter of dit antropocentrisme een model van verbondenheid uitsluit. Ten tweede is er de kritiek dat door de demystificatie van de natuur als schepping door God - een demystificatie die later geconsolideerd werd door de moderne wetenschap die 'schepping' vervangt door 'universum' - de mens tot een houding van heerser over de natuur aangemoedigd wordt. 


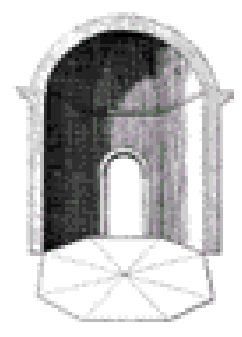

Opnieuw een terechte kritiek, maar geen garantie dat de personalist deze houding van heerser op de meest desastreuze wijze moeten invullen. Met andere woorden: het personalisme ontmoet hier duidelijk een grens, een grens die ingebakken zit in het christelijke wereldbeeld. De vraag is echter of dit een onoverkomelijke grens is t.a.v. de ontwikkeling van een adequate personalistische bedrijfsethiek die een model van verbondenheid (o.a. van mens en natuur) en verantwoordelijkheid (o.a. van de mens voor de natuur) hanteert. Want daarover gaat het precies, en het is mogelijk aan te tonen dat deze elementen van verbondenheid en verantwoordelijkheid niet het voorrecht zijn van holistische en/of ecofilosofische denkers, maar dat zij zelfs deel zijn van de personalistische traditie zelf. Wel moeten deze concepten anders ingevuld worden dan totnogtoe (bijvoorbeeld bij Mounier) gedaan werd. Ik geef hier enkele suggesties:

Ten eerste verbondenheid dus. In de christelijke traditie vinden we denkrichtingen die de verbondenheid van alles in het bijzonder beklemtonen. Ik denk dat de mystieke traditie hier bij uitstek een voorbeeldfunctie kan hebben. Zoals elke mystiek benadrukt zij de eenheid van al het bestaande. Op deze basis kan, in tegenstelling tot Mounier die vooral de verbondenheid van arbeiders onder elkaar en met hun bedrijf beklemtoont, de verbondenheid van mens en natuur (en dus ook bedrijf en natuur) in het licht gesteld worden. De persoon wordt dan gezien als deel van de natuur.

Ten tweede is er verantwoordelijkheid. Deze vloeit in zekere zin uit het voorgaande punt voort. Aangezien de mens inziet dat hij als persoon deel is van de natuur, besluit hij (uit eigenbelang wellicht) dat het beter is dit 'leefmilieu' op een adequate manier te behandelen, namelijk: adequaat t.o.v. de behandeling die hij ook voor zichzelf als persoon opeist. Met andere woorden: de gewenste relaties van niet-instrumentaliteit tussen de mensen wordt overgedragen op de natuur, omdat (en hier komt het mystieke weer enigszins terug) er uiteindelijk een zekere identiteit (of tenminste deelname) wordt vastgesteld tussen persoon en natuur.
Beide thema's, verbondenheid en verantwoordelijkheid, vinden we terug in het werk van de cristelijk geïnspireerde Dostojevski, bijvoorbeeld in De gebroeders Karamazov (1879/1880). Ik denk hier in het bijzonder aan de gedachte dat we verantwoordelijk zijn t.o.v. iedereen en alles, en $i k$ eerst. Een dergelijke verantwoordelijkheid (in de traditie eerder uitgedrukt als schuld) veronderstelt een zeer vergaande spirituele verbondenheid van al het bestaande en alle mensen. Een dergelijke verbondenheid gaat veel verder dan de "(her)ontdekking van het spirituele in de persoon maar ook in het profane en het maatschappelijke leven" (Bouckaert 2000: 226). Het sluit ook het niet-persoonlijke en niet-maatschappelijke in, met andere woorden: ook de 'natuur', de schepping voor de christen. Levinas (1972) heeft Dostojevski's thema van radicale verantwoordelijkheid opgenomen, maar ziet deze vooral m.b.t. de ander en de Ander, zonder expliciet de natuur (of de schepping) te vermelden. In elk geval is het een thema dat een lange traditie heeft in het christelijke (en door christelijke ideeën geïnspireerde) denken, en waarop ik hier niet in kan gaan.

Ik wil hier de situatie van de personalist niet te rooskleurig inschatten. We zien dat ondanks de mogelijke bruggen die ik hier geschetst heb, de spanning tussen de twee modellen blijft bestaan. Antropocentrisme en demystificatie van de natuur blijven knelpunten. Wel hoop ik dat deze reflectie een aanknopingspunt biedt voor verdere dialoog tussen beide modellen.

\section{Besluit}

Wat kunnen dergelijke gedachten over grenzen en mogelijkheden van het personalisme nu betekenen voor een bedrijfsethiek? Het is zeker dat op basis van deze ideeën verder nagedacht kan worden over voorstellen tot herstructurering van het economische leven en van de manier waarop bedrijven werken. Deze voorstellen zullen verder moeten gaan dan de idee van economische democratie: voorbij het concept persoon (de werkgever/de werknemer/de consument/relaties tussen personen) 


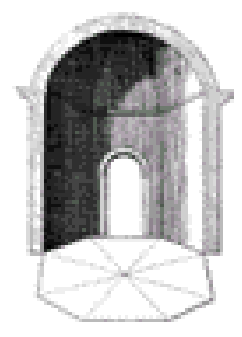

naar de natuur, en (wat het personalisme betreft) tegelijk toch mét het concept persoon. Er zijn grofweg twee mogelijkheden:

De verbinding van allen met alles wordt gerealiseerd door de staat in één groot systeem. Deze idee negeert het tweede luik "met het concept persoon": de persoon gaat onder in het systeem. Dit is het totalitarisme, en duidelijk geen echte mogelijkheid voor het personalisme. "Niets gaat meer in tegen het personalisme dan het zo vaak voorkomende streven naar een systeem van denken en handelen, dat automatisch oplossingen en aanbevelingen verschaft, het zoekproces verlamt..." (Mounier in: Bouckaert 2000: 221).

Het creatieve zoeken naar en experimenteren met economische democratie door de personen zélf, met name door de personen die betrokken zijn bij het bedrijf. Dit ben ' $i k$ in de eerste plaats': iedereen dus, niet alleen de bedrijfsleiding, de werknemers, en de klanten of consumenten, want iedereen is uiteindelijk verbonden en verantwoordelijk voor wat gebeurt. Bedrijfsethiek is ook een zaak van de toekomstige generaties en de natuur. Er zijn vandaag reeds voldoende groepen en organisaties die bereid zijn deze belangen te vertegenwoordigen; de zaak is dan hen ook werkelijk en systematisch bij beslissingsprocessen van bedrijven te betrekken. Dit is inderdaad een utopie, een utopie van economische democratie die veel verder gaat dan die van Mounier, maar die de personalistische gedachte van vrije en creatieve personen behoudt. De vernieuwende idee is dan dat we niet alleen tot verantwoordelijke personen worden door verantwoordelijkheid op te nemen voor ons bedrijf, maar ook door voor de belangen van anderen in de samenleving (ook internationaal en supra-nationaal) op

\section{Bibliografie}

L. BOUCKAERT, 'Mounier en de utopie van economische democratie' in Ethische Perspectieven 10(2000)4, p. $221-230$.

F. DostojeVsKI, F. (1879/1880), De gebroeders Karamazov. Contact, 2000.

E. LEVINAS, Humanisme de l'autre homme. Montpellier, Fata Morgana, 1972. te komen die uiteindelijk toch met ons te maken hebben. Uiteindelijk worden we dan pas echt persoon als we ons ook verantwoordelijk voelen voor de natuur, in christelijke termen: de schepping die ons door God is gegeven, waarmee we sterk verbonden zijn, en waarvoor we (en dus ook $i k)$ verantwoordelijk zijn.

Er zijn vandaag reeds belangrijke denkstappen gedaan in het denken over economische democratie. Teveel echter blijven het ideeën, en blijft de huidige situatie voortduren. Deze bestaat in het (al dan niet) ingrijpen van de overheid achteraf, als de gevolgen van acties van bedrijven zichtbaar of voelbaar worden in de bredere samenleving. Dit toont aan dat verantwoordelijkheid en schuld toch niet te ontlopen zijn. Vroeg of laat raakt iedereen er zichtbaar en voelbaar bij betrokken, want de verbondenheid is er altijd geweest. Mijn voorstel in dit essay is om direct bij de bron, vooraf dus, iets te ondernemen in de richting van economische democratie. Dit kan zeker door de overheid gestimuleerd worden, maar mag niet opgelegd worden. Het christelijk personalisme gelooft precies in de mens als persoon, in zijn creativiteit en mogelijkheden, en in de toekomst van deze mens. Het gelooft dat het individu uit zichzelf kan treden, dat het de vrijheid heeft om zich te transformeren tot een verantwoordelijke persoon. De vrijheid die zich in dit engagement manifesteert is niet enkel een vrijheid die voortkomt uit de betrokkenheid op de ander (Mounier in: Bouckaert 2000: 224), maar die ook uitdrukking is van een diepere verbondenheid: de verbondenheid met de Ander (Levinas), de ultieme Persoon, wiens liefde niet alleen zichtbaar en voelbaar wordt in het gezicht van de andere persoon, maar ook in het levende lichaam van de natuur. 